\title{
Antagonistic Potential of Native Isolates of Trichoderma longibrachiatum and Pseudomonas fluorescens against Alternaria porri (Ellis) Cif.
}

\author{
Karamsi Sailaja Bai* and P. Balabaskar
}

Parasitoid Taxonomy and Biocontrol Laboratory, Department of Entomology, Faculty of Agriculture, Annamalai University, Chidambaram-608002, Tamil Nadu, India

*Corresponding author

\begin{tabular}{|c|c|}
\hline & A B S T R A C T \\
\hline 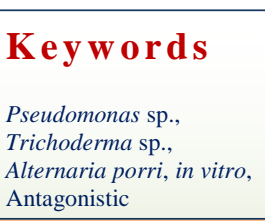 & \multirow{3}{*}{$\begin{array}{l}\text { The aim of the study was to access the anti-bacterial and anti-fungal activity on the growth } \\
\text { of Alternaria porri under in vitro condition. The antagonistic activity of bacterial and } \\
\text { fungal antagonists (Pseudomonas and Trichoderma spp.) was determined by the dual } \\
\text { culture technique both on King's B and PDA media respectively, Paper disc assay and } \\
\text { Agar well mathod. Plates were incubated at } 28^{\circ} \mathrm{C} \text { for } 7 \text { days and } 2 \text { days. The antagonistic } \\
\text { activity of these antagonists was evaluated by mycelial growth and mycelial dry weight of } \\
\text { test fungus (Alternaria porri). Among the bacterial antagonists (P. fluorescens, B. subtilis, } \\
B \text {. cereus, Serratia marescens and } P . \text { putida) and fungal antagonists (T. viride, T. } \\
\text { harzianum, T. longibrachiatum and T. virens) tested, P. fluorescens and T. } \\
\text { longibrachiatum were found to be effective to A. porri as they recorded the maximum } \\
\text { percent inhibition compared to others. }\end{array}$} \\
\hline Article Info & \\
\hline $\begin{array}{l}\text { Accepted: } \\
\text { 20 May } 2018 \\
\text { Available Online: } \\
\text { 10 June } 2018\end{array}$ & \\
\hline
\end{tabular}

\section{Introduction}

Onion (Allium cepa L.) a bulbous, biennial herb, rightly called as "Queen of kitchen" is one of the most important vegetable crops grown throughout the world. It belongs to the family Alliaceae. The genus Allium contains 300 species.

The primary Centre of origin of onion is Central Asia (Vavilov, 1951) and Near East Asia. Onion considered as poor man's staple spice. It contains several medicinal properties and it cures many chronic diseases. Chemical composition of onion is anti-inflammatory, anti-cholesterol, anticancer and antioxidant properties such as quercetin (Slimestad et al.,
2007). India ranks first in area under onion cultivation. In the world it occupies the total area of 11.5 Lakh ha, Production of 187.36 Lakh MT and Productivity of 16.29 t/ha (NHRDF, Nashik, 2015).

In India, area under onion is 1173.36000 ha, production of 187.36 Lakh MT and productivity of $16.13 \mathrm{t} / \mathrm{ha}$ (NHRDF, Nashik, 2015). Onion is affected by 66 diseases including 10 bacterial, 38 fungal, six nematode, three viral, one mycoplasma, one parasitic plant and seven miscellaneous diseases and disorders (Schwartz and Mohan, 2010). Of these, purple blotch of onion caused by Alternaria porri (Ellis) Cif, is the most destructive foliar disease, prevalent in almost 
all onion growing areas of the world. The disease causes a significant reduction in seed and bulb yield, with seed losses up to $100 \%$ (Abo-Elyousr et al., 2014).

Now a days, different chemicals including systemic and contact fungicides have been used for the management of this disease (Rahman et al., 2003). Certain fungicides such as chlorothalonil, zineb, mancozeb and propineb are effective on Alternaria porri but are not considered as a safe approach to gain more yield. Accumulation of chemicals in the soil result in soil pollution, nutrient loss, killing of non-target beneficial microbes. Intensive use of fungicides has not only resulted in the accumulation of toxic compounds but is potentially hazardous to human and environment (Reshu and Khan, 2012).

Recent studies include use of antagonistic micro-organisms which has been considered a more natural and environmentally acceptable alternative to the existing chemicals (Eziashi et al., 2007). In recent years, interest in the use of bacteria for biological control of plant pathogenic fungi has increased (Haas and Keel, 2003; Ravicharan et al., 2011), especially the use of plant growth promoting rhizobacteria (Raaijmakers and Weller, 2001; Weller et al., 2002).

Among the various antagonistic bacteria used for the management of plant diseases, PGPR play a vital role and it has been reported to improve plant growth either through direct stimulation of the plant or by suppression of pathogens (Osorio et al., 2012).

The virulent culture of P.fluorescens was obtained from the culture collection centre of Department of Agricultural Plant Pathology, Annamalai University were taken for the study. Fungal antagonist $T$. longibrachiatum was isolated from rhizosphere soil.

\section{Materials and Methods}

The virulent culture of P.fluorescens was obtained from the culture collection centre of Department of Agricultural Plant Pathology, Annamalai University were taken for the study. Fungal antagonist $T$. longibrachiatum was isolated from rhizosphere soil. Trichoderma spp. was isolated from rhizosphere soil collected from Sivapuri village. The soil particles loosely adhering to the roots were gently teased out and used for the isolation of Trichoderma spp. following serial dilution plate technique with Trichoderma selective medium. A soil suspension was prepared from rhizosphere sample by shaking $1 \mathrm{~g}$ of soil sample in $10 \mathrm{ml}$ of sterile distilled water and serial dilutions were made. From the $10^{-5}$ soil dilution $1 \mathrm{ml}$ was transferred into sterile Petri dish under aseptic condition in which $15 \mathrm{ml}$ of sterile Trichoderma selective medium was poured, gently rotated for uniform mixing of the soil dilution with the medium and incubated at room temperature $\left(28 \pm 2^{\circ} \mathrm{C}\right)$ for $5-7$ days. The isolate was purified by single spore method. The fungus was identified on the basis of morphological and reproductive characters and the pure culture of Trichoderma spp. was maintained on Trichoderma selective medium and stored at $4^{\circ} \mathrm{C}$.

Effect of culture filtrates of $\boldsymbol{P}$. fluorescens and $T$. longibrachiatum on the mycelial growth of $A$. porri by poisoned food Technique-Grover, R.K. and Moore. R.D. (1962)

The culture filtrate of $P$. fluorescens and $T$. longibrachiatum were separately incorporated into sterilized PDA medium at 10, 20, 30, 40 and 50 per cent by adding the calculated quantity of the culture filtrate to the medium by means of a sterile pipette. The PDA medium without the culture filtrate served as control. The amended media were transferred 
to sterile Petri dishes separately @ $15 \mathrm{ml}$ and allowed to solidify. Each plate was inoculated at the centre with seven days old $(9 \mathrm{~mm})$ PDA culture disc of $A$. porri. Mancozeb 0.2 per cent conc. was used for comparison. The diameter of the mycelial growth (in $\mathrm{mm}$ ) of $A$. porri was measured when the mycelial growth fully covered the control plates.

Effect of culture filtrates of $\boldsymbol{P}$. fluorescens and $T$. longibrachiatum on the mycelial growth of $A$. porri by Paper disc assay (Saha et al., 1995) and Agar well method (Gupta et al., 2001 a)

In Poisoned food technique, various concentrations of CMFF 136 fungicidal solution and various concentrations of $T$. longibrachiatum were prepared separately. 20 $\mathrm{ml}$ of PDA medium was poured into the sterilized Petri plate and allowed to solidify for 10-15 min. Sterile filter paper discs (9 $\mathrm{mm}$ ) were dipped separately at known concentration of treatments and placed equidistantly over the medium.

Three replications were maintained with individual concentration of both chemical and culture filtrate of the antagonist. The plates were incubated at $28 \pm 2^{0} \mathrm{C}$ for $48 \mathrm{~h}$. The inhibition zone of the fungal growth around the treated paper discs was measured and recorded. The plates without any chemical and bio control agent were served as control.

In Agar well method, four wells (5 $\mathrm{mm}$ dia) were prepared with the help of a sterile cork borer on potato dextrose agar plates two $\mathrm{cm}$ just opposite to each other. The culture filtrate $(50 \mu 1)$ of different antagonists was pipetted out into each well. The actively growing mycelial disc of $A$. porri was inoculated at the center of each plate. The plates were incubated and inhibition zone formed was recorded after seven days and per cent inhibition on growth was calculated.
In vitro efficacy of biocontrol agents against A. porri by Dual culture Technique (Dennis and Webster, 1971)

Fifteen $\mathrm{ml}$ of sterilized PDA medium was poured into sterile Petri dishes under aseptic conditions and allowed to solidify. After solidification, nine mm culture disc of A.porri (10 days old) was inoculated at $1.5 \mathrm{~cm}$ away from the edge of the Petri dish. Similarly, culture disc of $T$. longibrachiatum was placed at equidistance away from the other edge of the Petri dish. In case of bacterial antagonists one $\mathrm{cm}$ long streak was gently made onto the medium using two days old culture just opposite to the pathogenic culture at equidistance. Petri dishes inoculated with pathogen alone served as control. Three replications were maintained for each treatment. The inoculated Petri dishes were incubated in a BOD incubator at $28 \pm 2{ }^{\circ} \mathrm{C}$ for seven days. The zone of inhibition (in $\mathrm{mm}$ ) and the M090mycelial growth of A.porri were recorded after the incubation period. The effective antagonists were selected based on the inhibition of pathogen. The per cent inhibition of mycelial growth was calculated according to Vincent (1927) as follows.

Per cent inhibition $(\mathrm{I})=(\mathrm{C}-\mathrm{T} / \mathrm{C}) \times 100$

Where, $\mathrm{I}=$ inhibition per cent; $\mathrm{C}=$ radial growth of the pathogen in control and $\mathrm{T}=$ radial growth in treatment.

\section{Results and Discussion}

Efficacy of certain bacterial antagonists against $A$. porri by Dual Culture Technique

The results of the dual culture technique indicated that all the antagonists inhibited the growth of test fungus significantly when compared to control (Table 1). Among the antagonists P.fluorescens was found to be more 
Table.1 Efficacy of certain bacterial biocontrol agents against $A$. porri by Dual culture Technique

\begin{tabular}{|l|l|l|l|}
\hline S. No & Antagonistic organisms & $\begin{array}{l}\text { Mycelial } \\
\text { growth (mm) }\end{array}$ & $\begin{array}{l}\text { Percent } \\
\text { inhibition over } \\
\text { control (\%) }\end{array}$ \\
\hline $\mathbf{1}$ & Pseudomonas fluorescens & 19.43 & 78.42 \\
\hline $\mathbf{2}$ & Bacillus subtilis & 25.39 & 75.78 \\
\hline $\mathbf{3}$ & Serratia marescens & 22.42 & 74.08 \\
\hline $\mathbf{4}$ & Bacillus cereus & 27.45 & 69.50 \\
\hline $\mathbf{5}$ & Pseudomonas putida & 23.86 & 73.48 \\
\hline 6 & Control & 90.00 & - \\
\hline & SEd & 0.55 & 0.49 \\
\hline & $\mathrm{CD}=(\mathrm{p}=0.05)$ & 1.12 & 0.97 \\
\hline
\end{tabular}

Table.2 Efficacy of different species of Trichoderma against A. porri by Dual culture Technique

\begin{tabular}{|l|l|l|l|}
\hline $\begin{array}{l}\text { S. } \\
\text { No }\end{array}$ & $\begin{array}{l}\text { Antagonistic organisms } \\
\text { Trichoderma sp }\end{array}$ & $\begin{array}{l}\text { Mycelial } \\
\text { growth (mm) }\end{array}$ & $\begin{array}{l}\text { Percent } \\
\text { inhibition over } \\
\text { control (\%) }\end{array}$ \\
\hline $\mathbf{1}$ & Trichoderma viride & 21.72 & 75.87 \\
\hline $\mathbf{2}$ & Trichoderma harzianum & 23.22 & 74.20 \\
\hline $\mathbf{3}$ & Trichoderma longibrachiatum & 20.51 & 77.22 \\
\hline $\mathbf{4}$ & Trichoderma virens & 24.64 & 72.62 \\
\hline $\mathbf{5}$ & Control & 90.00 & - \\
\hline
\end{tabular}

Table.3 Evaluation of $P$. fluorescens against $A$. porri under in vitro condition by Paper disc assay and Agar well method

\begin{tabular}{|l|l|l|l|}
$\begin{array}{l}\text { Tr. } \\
\text { No. }\end{array}$ & $\begin{array}{l}\text { Conc. of the antagonist } \\
(\%)\end{array}$ & \multicolumn{2}{|c|}{ Inhibition Zone (mm) } \\
\cline { 3 - 4 } & 10 & Paper disc assay & Agar well method \\
\hline 1 & 10.14 & 6.87 \\
\hline 2 & 20 & 10.26 & 7.25 \\
\hline 3 & 30 & 13.59 & 10.63 \\
\hline 4 & 40 & 14.68 & 15.16 \\
\hline 5 & Control & 16.64 & 16.20 \\
\hline & SEd & $\mathbf{0 . 1 3}$ & 0.15 \\
\hline & CD $(\mathrm{p}=\mathbf{0 . 0 5})$ & 0.29 & 0.32 \\
\hline
\end{tabular}


Table.4 Evaluation of $T$. longibrachiatum against $A$. porri under in vitro condition By Paper disc assay and Agar well method

\begin{tabular}{|l|l|c|c|}
\hline $\begin{array}{l}\text { Tr. } \\
\text { No. }\end{array}$ & $\begin{array}{l}\text { Conc. of culture filtrate of } \\
\text { antagonist (\%) }\end{array}$ & \multicolumn{2}{|c|}{ Inhibition Zone (mm) } \\
\hline 1 & 10 & 7.11 & A gar well method \\
\hline 2 & 20 & 11.22 & $\mathbf{7 . 8 4}$ \\
\hline 3 & 30 & 14.55 & $\mathbf{8 3}$ \\
\hline 4 & 40 & 15.64 & 16.60 \\
\hline 5 & Control & 16.64 & 16.20 \\
\hline
\end{tabular}

Antagonistic to $A$. porri as it recorded the maximum percent inhibition $(77.22 \%)$ which was followed by $T$. viride $(75.87 \%)$ and $T$. harzianum (74.20\%).The minimum growth inhibition was recorded by $T$. virens (72.62\%). Certain bacterial antagonists like $P$. fluorescens, B. subtilis, Serratia marescens, $B$. cereus and $P$. putida were taken for comparing their inhibitory effect on the mycelial growth of $A$. porri. Among these, $P$. fluorescens recorded least mycelial growth compared to other bacterial antagonists. The fungistatic activity of $P$. fluorescens based on the inhibition of mycelial growth and mycelia dry weight of several pathogens was well established (Balabaskar, 2006; Sundaramoorthy et al., 2014). Different species of Trichoderma viz., $T$. viride, $T$. harzianum, $T$. longibrachiatum and $T$. virens were taken for comparing the effect on mycelial growth of A. porri. Among these, $T$. longibrachiatum recorded least mycelial growth compared to other species. These results were in agreement with laboratory experiments carried out against several foliar pathogens. The usage of Trichoderma as a biocontrol agent against the phytopathogens has been emphasized by Elad et al., (2002) and Pandey et al., (2011). Various conc. of $P$. fluorescens was evaluated by two methods such as Agar well and Paper disc assay and the results are summarized in table 3 . Maximum inhibition zones were recorded at $40 \%$ concentrtion. At $40 \%$ concentration the inhibition zones were $14.68 \%$ \& $15.16 \%$ in paper disc assay and agar well method respectively. The minimum inhibition zones were found at $10 \%$ conc. At $10 \%$ conc. the inhibition zones were 6.14 and 6.87 in paper disc assay and agar well method respectively. Various conc. of $T$. longibrachiatum was evaluated by two methods such as Agar well and Paper disc assay and the results are summarized in table 4. Maximum inhibition zones was recorded at $40 \%$ concentration. At $40 \%$ concentrtion the inhibition zones were $15.64 \% \& 16.12 \%$ in paper disc assay and agar well method respectively. The minimum inhibition zone was found at $10 \%$ conc. At $10 \%$ conc. the inhibition zones were $7.11 \&$ 7.84 in paper disc assay and agar well method respectively.

\section{References}

Abo-Elyousr, K.A.M., Abdel-Hafez, S.I.I. and Abdel-Rahim, I.R. 2014. Isolation of Trichoderma and evaluation of their antagonistic potential against Alternaria porri. Journal of Phytopathology, 162(9): 567-574.

Balabasker, P. 2006. Certain studies on the management of root rot of sesame (Sesame indicum L.) incited by Macrophomina phaseolina (Tassi) Goid. Ph. D. Thesis, Annamalai University, Tamilnadu, India.

Elad Y, B_elanger RR, Kohl J. (2002) Biological control of diseases in the phyllosphere. In: Albajes R, Lodovica 
Gullino M, Lenteren JC, Elad Y. (eds) Integrated Pest and Disease Management in Greenhouse Crops. The Netherlands, Springer, pp 338-352.

Eziashi EI, Omamor IB and Odigie EE (2007). Antagonism of Trichoderma viride and effects of extracted water soluble compounds from Trichoderma species and benlate solution on Ceratocystis paradoxa. African Journal of Biotechnology 6 388-392.

Haas, D and Keel, C. 2003. Regulation of antibiotic production in root colonizing Pseudomonas spp. And revelance for biological control of plant disease. Annual Review of Phytopath., 41: 117153.

NHRDF (National Horticultural Research and Development Foundation), 2015.

Osorio, J. A., Martinez, E.P. and Hio, J.C. 2012. Screening of microbial culture filtrates, plant extracts and fungicides for control of mango anthracnose. Agronomia Colobiana, 30: 222-229.

Raaijmakers, J.M., Weller, D.M. and Thomashow, L.S. 2001. Frequency of antibiotic producing Pseudomonas spp. in natural environments. Appl. Environ. Microbiol. 63: 881-887.

Rahman, M. A., Chiranjeevi, C. H. and Reddy, I. P. 2003. Management of leaf blight disease of onion. Approaches for sustainable development of onion and garlic. National Horticultural Research and Development Foundation, Nashik. pp. 311-314.
Ravicharan, A., Prathap Reddy, V., Narayana Reddy, P., Sokka Reddy, S. and Sivarmakrishnan, S. 2011. Assessment of genetic diversity in Pseudomonas fluorescens using PCR based methods Bioremidiation, Biodiversity and Bioavailability. Global Sci. Books, 5: 10-16.

Reshu and Khan MM, 2012. Role of different microbial-origin bioactive antifungal compounds against Alternaria spp. causing leaf blight of mustard. Plant Pathol. J., 11:1-9.

Schwartz HF, Mohan SK (2010) Compendium of onion and garlic diseases and pests (2nd edn) Am Phytopath Soc St Paul Minnesota, USA.

Slimestad R. Fossen T Vagen IM (2007). Onions: A source of unique dietary flavinoids. J Agric. Food Chem. 55(25): 10067-10080.

Sundaramoorthy, Ashok Kumar, and Sundaram Gunasekaran. 2014. Applications of graphene in quality assurance and safety of food. TrAC Trends in Analytical Chemistry 60: 3653.

Vavilov. 1951. The origin, variation, immunity and breeding of cultivated plants. Chronica Botanica Waltham, Mass, (USA).

Weller, D. M., Raaijmakers, J. M., Mc Spadden, G. B. B. and Thomashow, L. S. (2002). Microbial populations responsible for specific soil suppressiveness to plant pathogens. Annu. Rev. Phytopathol., 40: 309-348.

\section{How to cite this article:}

Karamsi Sailaja Bai and Balabaskar P. 2018. Antagonistic Potential of Native Isolates of Trichoderma longibrachiatum and Pseudomonas fluorescens against Alternaria porri (Ellis) Cif. Int.J.Curr.Microbiol.App.Sci. 7(06): 2672-2677. doi: https://doi.org/10.20546/ijcmas.2018.706.316 